\title{
KIPA-INIA, NEW HIGH YIELD SPRING BREAD WHEAT VARIETY FOR CHILE
}

\author{
Iván Matus $^{1 *}$, Ricardo Madariaga ${ }^{1}$, Claudio Jobet ${ }^{2}$, Javier Zúñiga², and Christian Alfaro ${ }^{3}$
}

\begin{abstract}
Kipa-INIA is a spring wheat variety (Triticum aestivum L.) originated from a cross carried out in the Wheat Plant Breeding Project of the Instituto de Investigaciones Agropecuarias (INIA), in the Centro Regional de Investigación Quilamapu (36³1' S; 71 $54^{\circ}$ 'W) in 1993. It has an upright growth habit in the seedling stage. The adult plant is low to medium height and varies between 90 and $95 \mathrm{~cm}$. The spike is white with long awns along its full length. The grain is ovate, white, and vitreous. It was sown in mid-August in the Santa Rosa Experimental Field, Chillán, head emergence occurred 90 to $95 \mathrm{~d}$ after sowing, i.e. is 4 to $6 \mathrm{~d}$ before 'Domo-INIA'. On the mean, 'Kipa-INIA' sown under irrigation conditions reached a yield of $11.7 \%$ higher than the control var. Domo-INIA, and $18.1 \%$ higher in dryland soils.
\end{abstract}

Key words: spring wheat, Triticum aestivum, new cultivar, Kipa-INIA.

$\mathrm{V}$ arieties of spring bread wheat are cultivated in a broad range of climates and soils in Chile and must meet various requirements in order to be registered as varieties. Among these requirements are high yield potential, good industrial quality, and good behavior towards diseases, especially foliar diseases. 'Kipa-INIA' meets these requirements and stands out for its high yield potential and wide adaptation, as well as exhibiting white vitreous grains.

\section{Origin}

Kipa-INIA is a spring wheat variety (Triticum aestivum L.) originating from a cross carried out in the Instituto de Investigaciones Agropecuarias (INIA) National Wheat Program in the Centro Regional de Investigación Quilamapu in 1993. The $F_{2}$ to $F_{7}$ selection stages were carried out between 1995 and 2000 using the pedigree method. It was evaluated in a preliminary yield trial in 2001 and included in the main yield trial in 2002. It was studied in INIA's standard (locations) yield trials between

\footnotetext{
${ }^{1}$ Instituto de Investigaciones Agropecuarias INIA, Casilla 426, Chillán, Chile. "Corresponding author (imatus@inia.cl).

${ }^{2}$ Instituto de Investigaciones Agropecuarias INIA, Casilla 58-D, Temuco, Chile.

${ }^{3}$ Instituto de Investigaciones Agropecuarias INIA, Casilla 13, Rengo, Chile.

Received: 29 September 2010.

Accepted: 4 January 2011.
}

2003 and 2008, and these trials were registered as variety trials from 2004 to 2007, applying for registration of varieties suitable for certification (RVSC), a condition required by the Ministry of Agriculture through the Servicio Agrícola y Ganadero (Agriculture and Livestock Service). It was identified in all these trials as QUP 30652001.

\section{Crossing and pedigree}

The following is the genealogy of Kipa-INIA:

$$
\begin{aligned}
& \text { QUP 1867-91/DOMO-INIA } \\
& \text { C }-2636-5 \mathrm{C}-2 \mathrm{C}-8 \mathrm{C}-1 \mathrm{C}-1 \mathrm{C}-0 \mathrm{C} \text {. }
\end{aligned}
$$

\section{Morphological description of the plant}

This is a spring wheat variety with upright growth in the seedling stage. The adult plant is medium height between 90 and $95 \mathrm{~cm}$ (Figure 1). It normally exhibits plants with atypical height, which is common in semidwarf wheat varieties as indicated by Worland and Law (1985) and Storlie and Talbert (1993). The leaf sheath of the flag leaf has nil to very weak glaucocity. The auricle lacks antocianin, which explains its white color. The stalk medulla is thin and has low to moderate resistance to lodging.

\section{Spike characteristics}

The spike is white, semi-lax to semi-compact, approximately 10 to $11 \mathrm{~cm}$ long, strong glaucocity, semi- 
decumbent at maturity, pyramid-shaped, and long owns along its full length (Figure 2). The peak of the lower lemma of the spikelet in the middle Figure 2 third of the stem is straight.

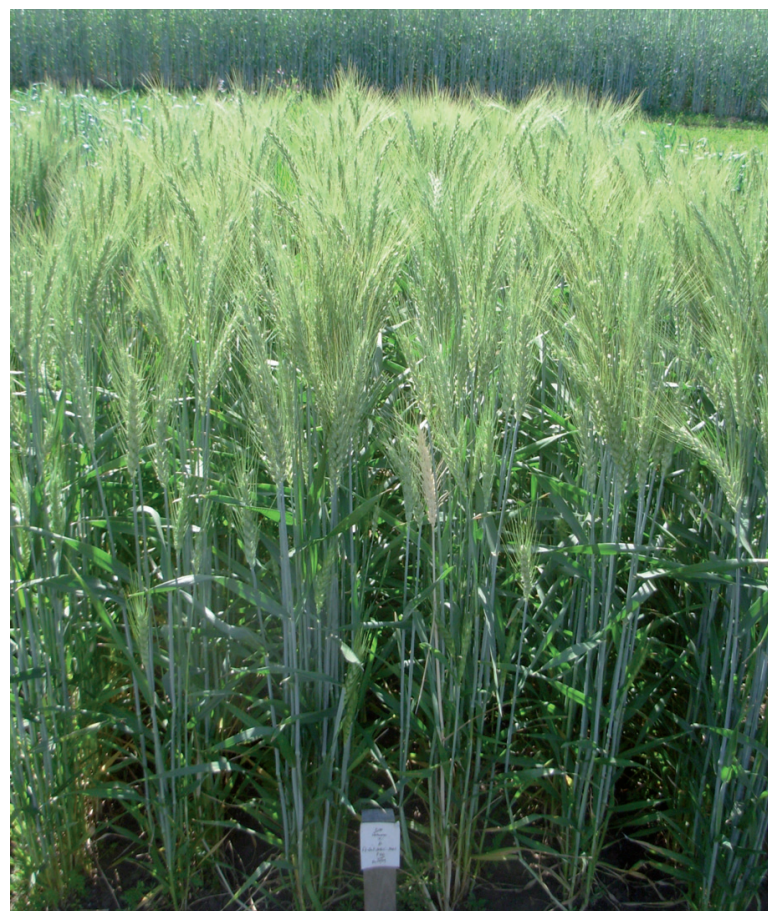

Figure 1.Adult plant of Kipa-INIA planted in Quilamapu. Santa Rosa Experimental Station.

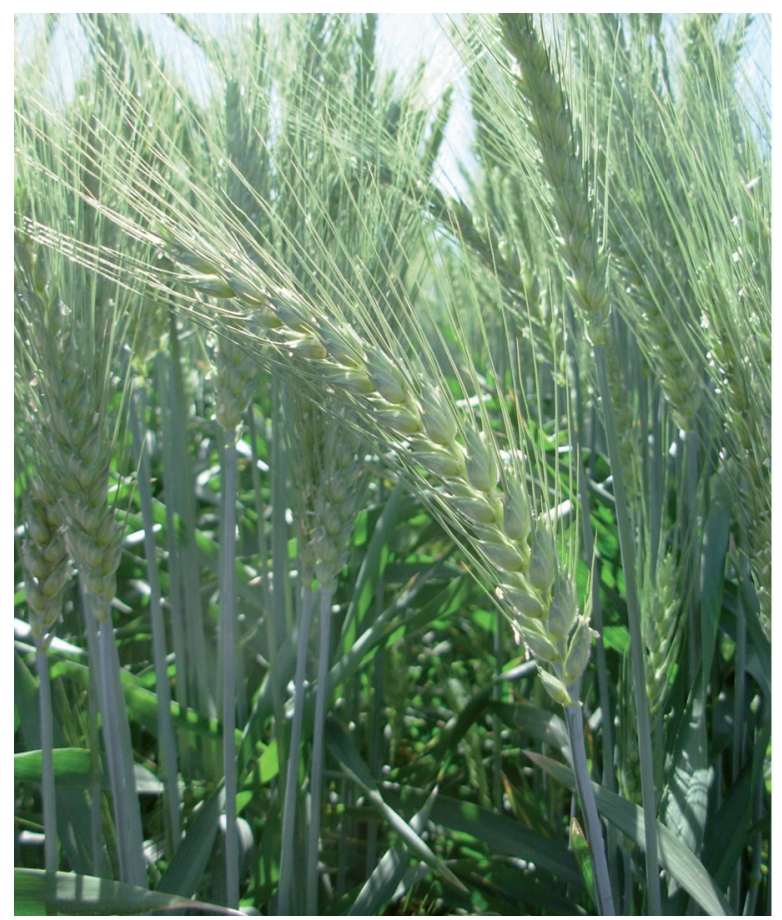

\section{Grain characteristics}

The grain is medium to large-sized, ovate, white, and vitreous. The percentage weight of seeds retained in a 2.3 $\mathrm{mm}$ oblong mesh sieve was $93 \%$ on the mean, and the weight of 1000 seeds was 44 to $48 \mathrm{~g}$. It exhibits nil or very weak coloration to phenol.

\section{Agronomic characteristics}

It was sown in mid-August in the Santa Rosa Experimental Station ( $36^{\circ} 31^{\prime}$ S; $\left.71^{\circ} 54^{\prime} \mathrm{W}\right)$, Chillán, head emergence occurred 90 to $95 \mathrm{~d}$ after sowing, and was 4 to $6 \mathrm{~d}$ before 'Domo-INIA' (Mellado et al., 1993).

\section{Phytopathological characteristics}

Up to the 2008-2009 season, var. Kipa-INIA showed resistance to moderate resistance to stripe rust (Puccinia striiformis West. f. sp. tritici), and leaf rust (Puccinia triticina Erikss.), and resistance to stem rust (Puccinia graminis Pers. f. sp. tritici Erikss. and Henn.), and low to moderate resistance to powdery mildew caused by the Blumeria graminis DC. f. sp. tritici Marchal fungus. It has exhibited resistance to leaf blotch (Mycosphaerella graminicola (Fuckel) J. Schröt.) (Tables 1 and 2).

\section{Grain yield}

Standard trials conducted in irrigated soils and dryland

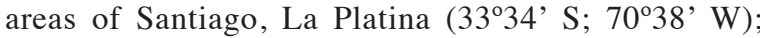
Ñuble, Quilamapu, ( $36^{\circ} 31^{\prime} \mathrm{S}$; $\left.71^{\circ} 54^{\prime} \mathrm{W}\right)$; Yungay $\left(37^{\circ} 08^{\prime} \mathrm{S} ; 7^{\circ} 0^{\prime} \mathrm{W}\right)$ Humán $\left(37^{\circ} 26^{\prime} \mathrm{S} ; 7^{\circ} 14^{\prime} \mathrm{W}\right)$; Temuco, Carillanca ( $\left.38^{\circ} 41^{\prime} \mathrm{S} ; 72^{\circ} 25^{\prime} \mathrm{W}\right)$; and Osorno, Purranque ( $\left.36^{\circ} 31^{\prime} \mathrm{S} ; 71^{\circ} 54^{\prime} \mathrm{W}\right)$ were evaluated from 2003 to 2008. In irrigated locations, 'Kipa-INIA' reached a mean yield of $11.7 \%$ higher than the control 'Domo-INIA' (Table 3), whereas the yield in dryland soils was $18.1 \%$ higher (Table 4). In all locations, whether irrigated or dryland, 'Kipa-INIA' was statistically equal to or higher than the control 'DomoINIA' (Tables 3 and 4).

\section{Quality}

Kipa-INIA is a wheat variety with a good hectoliter weight and a hard texture. Numbers for Zeleny sedimentation, wet gluten, and protein classify it as intermediate wheat (INN, 2000). It exhibits good bread volume, high W value, and a good $\mathrm{P} / \mathrm{L}$ ratio. This value is the relationship between dough tenacity and extensibility, a stability index used as a guideline to determine if dough has reduced, balanced, or high extensibility. In general, it is located in the category of wheat for direct bread-making (Table 5).

Figure 2. Spike of Kipa-INIA. 
Table 1. Behavior of cv. Kipa-INIA to stripe rust (Puccinia striiformis), leaf rust (P. triticina), stem rust (P. graminis), powdery mildew (Blumeria graminis), and leaf blotch (Septoria tritici) in four irrigated locations.

\begin{tabular}{|c|c|c|c|c|c|c|}
\hline Location & Year & $\begin{array}{c}\text { Yellow } \\
\text { rust }^{1}\end{array}$ & $\begin{array}{l}\text { Leaf } \\
\text { rust }^{1}\end{array}$ & $\begin{array}{c}\text { Steam } \\
\text { rust }^{1}\end{array}$ & $\begin{array}{l}\text { Powdery } \\
\text { mildew }^{2}\end{array}$ & $\begin{array}{c}\text { Leaf } \\
\text { blotch }\end{array}$ \\
\hline \multirow[t]{6}{*}{ La Platina } & 2003 & 0 & TR & 0 & 5 & 0 \\
\hline & 2004 & 0 & 0 & 0 & 0 & 0 \\
\hline & 2005 & 0 & 0 & 0 & 0 & 0 \\
\hline & 2006 & 0 & 0 & 0 & 0 & 0 \\
\hline & 2007 & 0 & 0 & 0 & 0 & 0 \\
\hline & 2008 & 0 & 0 & 0 & 0 & 0 \\
\hline \multirow[t]{6}{*}{ Quilamapu } & 2003 & 0 & $5 \mathrm{MS}$ & 0 & 2 & 0 \\
\hline & 2004 & 0 & $5 \mathrm{MR}$ & 0 & 0 & 0 \\
\hline & 2005 & $5 \mathrm{MR}$ & TMS & 0 & 0 & 0 \\
\hline & 2006 & 0 & $5 \mathrm{MS}$ & 0 & 0 & 3 \\
\hline & 2007 & $5 \mathrm{MS}$ & TMS & 0 & 0 & 0 \\
\hline & 2008 & $20 \mathrm{MR}$ & $5 \mathrm{MS}$ & 0 & 0 & 0 \\
\hline \multirow[t]{6}{*}{ Yungay } & 2003 & 0 & 0 & 0 & 3 & 0 \\
\hline & 2004 & 0 & 0 & 0 & 0 & 0 \\
\hline & 2005 & 0 & TMS & 0 & 0 & 0 \\
\hline & 2006 & 0 & 0 & 0 & 0 & 0 \\
\hline & 2007 & 0 & 0 & 0 & 0 & 0 \\
\hline & 2008 & 0 & 0 & 0 & 0 & 0 \\
\hline \multirow[t]{6}{*}{ Humán } & 2003 & 0 & 0 & 0 & 0 & 0 \\
\hline & 2004 & 0 & 0 & 0 & 0 & 0 \\
\hline & 2005 & $5 \mathrm{MS}$ & TMS & 0 & 0 & 0 \\
\hline & 2006 & $20 \mathrm{MR}$ & 0 & 0 & 0 & 0 \\
\hline & 2007 & 0 & TMS & 0 & 0 & 0 \\
\hline & 2008 & 0 & $5 \mathrm{MS}$ & 0 & 0 & 0 \\
\hline
\end{tabular}

${ }^{1}$ Values according to modified Cobb Scale (Peterson et al., 1984) where attack intensity can vary between 0 and $100 \%$ ( $\mathrm{T}=$ traces), plant reaction can be: resistant (R), moderately resistant (MR), moderately susceptible (MS), or susceptible (S).

${ }^{2}$ Values Saari and Prescott (1975) scale. Scale from 1 to 9.

\section{Cultivation area and sowing dates}

Data obtained in the standard trials allow recommending sowing 'Kipa-INIA' from the Metropolitan Region to the Los Lagos Region.

Sowing is recommended from June to August in irrigated soils, in May for interior dryland, from mid-June to mid-July in the dryland foothills, and from mid-August to the end of September in the wet dryland of the La Araucanía and Los Lagos Regions.

\section{Electrophoresis of high molecular weight glutenins}

'Kipa-INIA' exhibits allele $2 *$ in locus Glu1A, allele 7 in locus GluB, and alleles $5+10$ in locus Glu1D. In accordance with this classification, on a scale of 4 to 10 , it reaches a value of 8 .

\section{Molecular analysis}

This variety does not carry the rye translocation 1BL.1RS, contains the Pin-a hardness allele, and also exhibits the aluminum tolerant $\mathrm{V}$ allele for locus ALMT1. 
Table 2. Behavior of cv. Kipa-INIA to stripe rust (Puccinia striiformis), leaf rust (P. triticina), stem rust (P. graminis), powdery mildew (Blumeria graminis), and leaf blotch (Septoria tritici) in three humid locations.

\begin{tabular}{|c|c|c|c|c|c|c|}
\hline Location & Year & $\begin{array}{c}\text { Yellow } \\
\text { rust }^{1}\end{array}$ & $\begin{array}{l}\text { Leaf } \\
\text { rust }^{1}\end{array}$ & $\begin{array}{c}\text { Steam } \\
\text { rust }^{1}\end{array}$ & $\begin{array}{l}\text { Powdery } \\
\text { mildew }^{2}\end{array}$ & $\begin{array}{c}\text { Leaf } \\
\text { blotch }^{2}\end{array}$ \\
\hline \multirow[t]{6}{*}{ Yungay* } & 2003 & - & - & - & - & - \\
\hline & 2004 & - & - & - & - & - \\
\hline & 2005 & - & - & - & - & - \\
\hline & 2006 & 0 & 0 & 0 & 0 & 4 \\
\hline & 2007 & 0 & 0 & 0 & 0 & 0 \\
\hline & 2008 & 0 & 0 & 0 & 0 & 4 \\
\hline \multirow[t]{6}{*}{ Carillanca } & 2003 & 0 & 0 & 0 & 0 & 3 \\
\hline & 2004 & 0 & 0 & 0 & 0 & 0 \\
\hline & 2005 & 0 & $5 \mathrm{MR}$ & 0 & 0 & 0 \\
\hline & 2006 & 0 & 0 & 0 & 0 & 4 \\
\hline & 2007 & 0 & 0 & 0 & 0 & 0 \\
\hline & 2008 & 0 & $10 \mathrm{MR}$ & 0 & 0 & 5 \\
\hline \multirow[t]{6}{*}{ Purranque* } & 2003 & 0 & 0 & 0 & 0 & 5 \\
\hline & 2004 & - & - & - & - & 0 \\
\hline & 2005 & 0 & 0 & 0 & 0 & 0 \\
\hline & 2006 & $\mathrm{TR}$ & 0 & 0 & 0 & 5 \\
\hline & 2007 & 0 & 0 & 0 & 0 & 0 \\
\hline & 2008 & - & - & - & - & - \\
\hline
\end{tabular}

${ }^{1}$ Values according to modified Cobb Scale (Peterson et al., 1984) where attack intensity can vary between 0 and $100 \%(\mathrm{~T}=$ traces), plant reaction can be: resistant (R), moderately resistant (MR), moderately susceptible (MS), or susceptible (S).

${ }^{2}$ Values Saari and Prescott (1975) scale. Scale from 1 to 9.

*Trial was not sown in Yungay in 2003, 2004, and 2005, and in Purranque in 2004 and 2008. 
Table 3. Grain yield of cv. Kipa-INIA compared to control cv. Domo-INIA in standard trials conducted in four irrigated locations from 2003 to 2008.

\begin{tabular}{|c|c|c|c|}
\hline \multirow[b]{2}{*}{ Location } & \multirow[b]{2}{*}{ Year } & \multicolumn{2}{|c|}{ Cultivars } \\
\hline & & Kipa-INIA & Domo-INIA \\
\hline & & $\longrightarrow$ & $a^{-1}$ \\
\hline \multirow[t]{7}{*}{ La Platina } & 2003 & 7.11a & $6.38 \mathrm{a}$ \\
\hline & 2004 & $6.51 \mathrm{a}$ & $5.96 \mathrm{a}$ \\
\hline & 2005 & $6.01 \mathrm{a}$ & $5.84 \mathrm{a}$ \\
\hline & 2006 & $2.85 \mathrm{a}$ & $3.40 \mathrm{a}$ \\
\hline & 2007 & 7.39a & $5.64 b$ \\
\hline & 2008 & $4.21 \mathrm{a}$ & $5.15 \mathrm{a}$ \\
\hline & Mean & 5.68 & 5.39 \\
\hline \multirow[t]{7}{*}{ Chillán } & 2003 & $8.59 a$ & $6.40 \mathrm{~b}$ \\
\hline & 2004 & $9.56 a$ & $8.33 b$ \\
\hline & 2005 & $9.78 \mathrm{a}$ & $8.99 \mathrm{a}$ \\
\hline & 2006 & $10.12 \mathrm{a}$ & $9.75 \mathrm{a}$ \\
\hline & 2007 & $5.96 a$ & $6.98 \mathrm{a}$ \\
\hline & 2008 & $9.31 \mathrm{a}$ & $9.67 \mathrm{a}$ \\
\hline & Mean & 8.89 & 8.35 \\
\hline \multirow[t]{7}{*}{ Yungay } & 2003 & $8.64 a$ & $7.09 \mathrm{~b}$ \\
\hline & 2004 & $6.91 \mathrm{a}$ & $5.25 \mathrm{~b}$ \\
\hline & 2005 & $8.67 \mathrm{a}$ & $6.92 b$ \\
\hline & 2006 & $10.44 a$ & $10.21 \mathrm{a}$ \\
\hline & 2007 & $9.25 \mathrm{a}$ & $7.69 b$ \\
\hline & 2008 & $10.12 \mathrm{a}$ & $8.27 \mathrm{~b}$ \\
\hline & Mean & 9.01 & 7.57 \\
\hline \multirow[t]{7}{*}{ Humán } & 2003 & $7.42 \mathrm{a}$ & $5.82 b$ \\
\hline & 2004 & $8.64 a$ & $8.13 \mathrm{a}$ \\
\hline & 2005 & $10.19 a$ & $9.29 \mathrm{a}$ \\
\hline & 2006 & $10.97 \mathrm{a}$ & $9.26 \mathrm{~b}$ \\
\hline & 2007 & $9.05 \mathrm{a}$ & $8.82 \mathrm{a}$ \\
\hline & 2008 & $9.17 \mathrm{a}$ & $7.86 \mathrm{~b}$ \\
\hline & Mean & 9.24 & 8.19 \\
\hline
\end{tabular}

Different letters between cultivars for each year and location are statistically different at $\mathrm{P}<0.01$.
Table 4. Grain yield of cv. Kipa-INIA compared to control cv. Domo-INIA in standard trials conducted in three humid locations from 2003 to 2008 .

\begin{tabular}{|c|c|c|c|}
\hline \multirow[b]{2}{*}{ Location } & \multirow[b]{2}{*}{ Year } & \multicolumn{2}{|c|}{ Cultivars } \\
\hline & & Kipa-INIA & Domo-INIA \\
\hline & & $\longrightarrow$ & $a^{-1}-$ \\
\hline \multirow[t]{7}{*}{ Yungay } & 2003 & - & - \\
\hline & 2004 & - & - \\
\hline & 2005 & - & - \\
\hline & 2006 & $8.21 \mathrm{a}$ & $6.71 b$ \\
\hline & 2007 & $9.63 \mathrm{a}$ & $8.85 b$ \\
\hline & 2008 & $6.88 \mathrm{a}$ & $6.71 \mathrm{a}$ \\
\hline & Mean & 8.24 & 7.42 \\
\hline \multirow[t]{7}{*}{ Carillanca } & 2003 & $9.77 \mathrm{a}$ & $8.12 b$ \\
\hline & 2004 & $9.20 \mathrm{a}$ & $8.27 \mathrm{a}$ \\
\hline & 2005 & $8.54 \mathrm{a}$ & $6.56 b$ \\
\hline & 2006 & $9.48 \mathrm{a}$ & $3.04 \mathrm{~b}$ \\
\hline & 2007 & $7.66 a$ & $8.69 a$ \\
\hline & 2008 & $7.85 \mathrm{a}$ & $7.84 \mathrm{a}$ \\
\hline & Mean & 8.75 & 7.09 \\
\hline \multirow[t]{7}{*}{ Purranque } & 2003 & $9.29 \mathrm{a}$ & $8.11 \mathrm{a}$ \\
\hline & 2004 & - & - \\
\hline & 2005 & $12.26 \mathrm{a}$ & $9.66 b$ \\
\hline & 2006 & $7.72 \mathrm{a}$ & $7.43 \mathrm{a}$ \\
\hline & 2007 & $10.55 \mathrm{a}$ & $8.04 b$ \\
\hline & 2008 & - & - \\
\hline & Mean & 9.95 & 8.31 \\
\hline
\end{tabular}

Different letters between cultivars for each year and location are statistically different at $\mathrm{P}<0.01$.

Trial was not sown in Yungay in 2003, 2004, and 2005, and in Purranque in 2004 and 2008. 
Table 5. Quality characteristics of cv. Kipa-INIA compared to control cv. Domo-INIA.

\begin{tabular}{|c|c|c|}
\hline \multirow[b]{2}{*}{ Characteristics $^{(1)}$} & \multicolumn{2}{|c|}{ Cultivars } \\
\hline & Kipa-INIA & Domo-INIA \\
\hline Hardness index, $\%^{(2)}$ & 15.90 & 17.70 \\
\hline Hectoliter weight, $\mathrm{kg} \mathrm{hL}^{-1}$ & 84.02 & 81.78 \\
\hline Zeleny sedimentation, $\mathrm{cm}^{3(3)}$ & 33.00 & 29.80 \\
\hline Wet gluten, $\%^{(4)}$ & 37.15 & 39.73 \\
\hline Protein ( $\mathrm{N} x$ 5.7), $\%$ & 9.90 & 9.80 \\
\hline Falling number, $\mathrm{s}^{(7)}$ & 458 & 416 \\
\hline Work $(\mathrm{W})^{(5)}$ & 190 & 176 \\
\hline Tenacity (P) & 135 & 93 \\
\hline Extensibility (L) & 34 & 59 \\
\hline Ratio (P/L) & 3.97 & 1.57 \\
\hline Bread volume, $\mathrm{cm}^{3(6)}$ & 1125 & 1000 \\
\hline
\end{tabular}

${ }^{(1)}$ Mean values of trials conducted in La Platina, Chillán, Yungay, Humán, Yungay-S, Carillanca, and Purranque from 2003 to 2007.

${ }^{(2)}$ Values of < 20: hard grain; 20-30: semi-hard grain; > 30: soft grain.

(3) Numbers from 17 to $26.9 \mathrm{~cm}^{3}$ soft wheat; 27 to $32.9 \mathrm{~cm}^{3}$ intermediate wheat, and $\geq 33 \mathrm{~cm}^{3}$ strong wheat.

(4)Values from 18 to 24.9: soft wheat; 25.0 to 29.9: intermediate wheat; $\geq 30$ : strong wheat.

${ }^{(5)}$ W value (alveogram): < 150: low; 150-200: medium; $>$ 200: good

${ }^{(6)}$ Bread volume: $<550$ : low; 550-600: good; > 600: very good.

${ }^{(7)}$ Protein, Falling number and hardness index, mean of 28 values in seven locations, in 2004, 2006, and 2007.

Evaluation scale source: INN, 2000, Laboratorio Farinología del Instituto de Investigaciones Agropecuarias (INIA) and Granotec.

\section{CONCLUSIONS}

This is a new variety of spring bread wheat with a good yield potential, good hectoliter weight, and hard texture. The grain is medium to large-sized, white, and vitreous. Numbers for Zeleny sedimentation, wet gluten, and protein classify it as intermediate wheat. In general, it is located in the category of wheat for direct bread-making. It exhibits resistance to moderate resistance to stripe rust, leaf rust, stem rust, powdery mildew, and leaf blotch.

Data obtained in the standard trials allow recommending sowing var. Kipa-INIA from the Metropolitan Region to the Los Lagos Region.

\section{RESUMEN}

Kipa-INIA, nueva variedad de trigo harinero de primavera de alto rendimiento para Chile. Kipa-INIA es un trigo harinero (Triticum aestivum L.) de primavera que proviene de un cruzamiento efectuado el año 1993 en el Proyecto de Fitomejoramiento de Trigo del Instituto de Investigaciones Agropecuarias (INIA), en el Centro Regional de Investigación Quilamapu. Es un trigo con hábito de crecimiento erecto al estado de plántula. La altura de la planta adulta se considera mediana, y varía entre 90 y $95 \mathrm{~cm}$. La espiga es de color blanco, de barbas largas presentes en toda su extensión. El grano es de color blanco, aspecto vítreo, y forma ovada. Sembrado a mediados de agosto en el Campo Experimental Santa

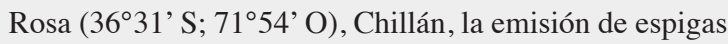
ocurre 90 a 95 días después de la siembra, entre 4 a 6 días antes que 'Domo-INIA'. En promedio sembrado bajo condiciones de riego, 'Kipa-INIA' alcanzó un rendimiento medio $11,7 \%$ mayor que la variedad testigo Domo-INIA y en suelos de secano tuvo un rendimiento superior de un $18,1 \%$ respecto de 'Domo-INIA'.

Palabras clave: trigo de primavera, Triticum aestivum, nuevo cultivar, Kipa-INIA.

\section{LITERATURE CITED}

INN. 2000. Trigo harinero. Requisitos. 16 p. NCh 1237. Of 2000. Instituto Nacional de Normalización (INN), Santiago, Chile.

Mellado, M., I. Matus, D. Granger, y R. Madariaga. 1993. Domo-INIA, variedad de trigo de primavera para la zona Centro Sur de Chile. Agricultura Técnica 53:82-84.

Peterson, R., J. Campbell, and A. Hannah. 1984. A diagrammatic scale for estimating rust intensity of leaves and stems of cereals. Canadian Journal of Research Section C-Botanical Sciences 26:496-500.

Saari, E., and J. Prescott. 1975. A scale for appraising the foliar intensity of wheat diseases. Plant Disease Reporter 59:377-380.

Storlie, E.W., and L.E. Talbert. 1993. Cause of tall offtypes in a semidwarf spring wheat. Crop Science 33:1131-1135.

Worland, A.J., and C.N. Law. 1985. Aneuploidy in semidwarf wheat varieties. Euphytica 34:317-327. 